\title{
A Global Perspective on Bilingualism and Bilingual Education: Implications for New Jersey Educators
}

\author{
(c) G. Richard Tucker
}

Carnegie Mellon University

E-mail-grtucker@andrew.cmu.edu

\section{Introduction}

The number of languages spoken throughout the world is estimated to be approximately 6,000 (Grimes 1992). Although people frequently observe that a small number of languages such as Arabic, Bengali, English, French, Hindi, Malay, Mandarin, Portuguese, Russian, and Spanish serve as important link languages or languages of wider communication around the world, these are often spoken as second, third, fourth, or later-acquired languages by their speakers (see, for example, Cheshire 1991; Comrie 1987; Edwards 1994). The available evidence seems to indicate that governments in many countries deliberately present a somewhat skewed picture of monolingualism as normative by the explicit or implicit language policies that they adopt and promulgate (Crystal 1987). Thus, fewer than $25 \%$ of the world's approximately 200 countries recognize two or more official languageswith a mere handful recognizing more than two (e.g., India, Luxembourg, Nigeria, etc.). However, despite these conservative government policies, available data indicate that there are many more bilingual or multilingual individuals in the world than there are monolingual. In addition, many more children throughout the world have been, and continue to be, educated via a second or a lateracquired language-at least for some portion of their formal educationthan the number of children educated exclusively via first language. In many parts of the world, bilingualism or multilingualism and innovative approaches to education that involve the use of two or more languages constitute the normal everyday experience (see, for example Dutcher 1994; World Bank 1995).

\section{Multiple languages in education}

The use of multiple languages in education may be attributed to, or be a reflection of, numerous factors: the linguistic heterogeneity of a country or region (e.g., Luxembourg or Singapore); specific social or religious attitudes (e.g., the addition of Sanskrit to mark Hinduism or Pali to mark Buddhism); or the desire to promote national identity (e.g., in India, Nigeria, the Philippines). In addition, innovative language education programs are often implemented to promote 
proficiency in international language(s) of wider communication together with proficiency in national and regional languages. The composite portrait of language education policies and practices throughout the world is exceedingly complex-and simultaneously fascinating. In Eritrea, for instance, an educated person will likely have attended some portion of schooling taught via Tigrigna and Arabic and English-and developed proficiency in reading these languages which are written using three different scripts (Ge'ez, Arabic, and Roman). In Oceania, to take a different example, linguists estimate that a mere $4 \%$ of the world's population speaks approximately $20 \%$ of the world's 6,000 languages. In Papua New Guinea, a country that has a population of approximately 3 million, linguists have described more than 870 languages (Summer Institute of Linguistics 1995). Here it is common for a child to grow up speaking one local indigenous language at home, another in the market place, adding Tok Pisin to her repertoire as a lingua franca, and English if she continues her schooling. Analogous situations recur in many parts of the world such as India, which has declared 15 of its approximately 1,650 indigenous languages to be "official;" or Guatemala, or Nigeria, or South Africa-to name but a few countries in which multilingualism predominates, and in which children are frequently exposed to numerous languages as they move from their homes into their communities and eventually through the formal educational system.

\section{Conclusions from extant research}

Nadine Dutcher (1994) and I carried out a comprehensive review for the World Bank of the use of first and second languages in education in which we examined, in some detail, the literature from research conducted in three different types of countries: (1) those with no (or few) mother tongue speakers of the language of wider communication (e.g., Haiti, Nigeria, the Philippines); (2) those with some mother tongue speakers of the language of wider communication (e.g., Guatemala); and (3) those with many mother tongue speakers of the language of wider communication (e.g., Canada, New Zealand, the United States).

Next I would like to describe what I hope will be a few of the familiar highlights of this review. These findings are consonant with those contained in "Section 3: Case Studies in Multilingual Education," in the splendid recent volume edited by Cenoz and Genesee (1998), as well as with the papers in the special issue of the Journal of Multilingual Multicultural Education (1996, volume 17), and with selected papers in two of the volumes of the Encyclopedia of Language and Education (Cummins and Corson 1997; Tucker and Corson 1997). Interested readers may also wish to review the excellent case study by Gonzalez 
and Sibayan (1988) and the recent volume by Baker and Jones (1998).

The personal research I have conducted over the past three decades in varied language education settings throughout the world, together with my reading of the available literature, leads me to a number of relatively straightforward conclusions:

- The language of school is very different from the language of home

- The development of cognitive/academic language requires time (four to seven years of formal instruction)

- Individuals most easily develop literacy skills in a familiar language

- Individuals most easily develop cognitive skills and master content material that is taught in a familiar language

- Cognitive/academic language skills, once developed, and content-subject material, once acquired, transfer readily

- The best predictor of cognitive/academic language development in a second language is the level of development of cognitive/academic language proficiency in the first language

- Children learn a second language in different ways depending upon their culture, their group, and their individual personality

Therefore, if the goal is to help the student ultimately develop the highest possible degree of content mastery and second-language proficiency, time spent instructing the child in a familiar language is a wise investment (i.e., Lambert's notion (1980) of "additive" bilingualism).

\section{Common programmatic threads}

Furthermore, Dutcher and I noted upon review that the following common threads cut across all of the successful programs that aim to provide students with multiple language proficiency and with access to academic content material (even though, we noted, there is a wide range of models available for implementation):

- Development of the mother tongue is encouraged for cognitive development, and as a basis for learning the second language

- Parental and community support and involvement are essential to all successful programs

- Teachers are able to understand, speak, and use the language of instruction with a high level of proficiency, whether it is their first or second language 
- Teachers are well trained, possess cultural competence and subject-matter knowledge, and continually upgrade their training

- Recurrent costs for innovative programs are about the same as they are for "traditional" programs (although there may be additional one-time start-up costs)

- Cost-benefit calculations can typically be estimated in terms of the cost savings to the education system, improvements in years of schooling, and enhanced earning potential for students with multiple language proficiency

The results from published, longitudinal, and critical research undertaken in various settings throughout the world clearly indicate that the development of multiple language proficiency is possible, and indeed viewed as desirable by educators, policy makers, and parents in many countries. Although this paper has a specific focus on bilingual education internationally, the findings summarized above are clearly consistent with those reported by researchers in the United States and in Canada (see, for example, Brisk 1998; Christian 1996; Thomas and Collier 1996).

\section{Cross-cutting theme}

Here I wish to comment briefly on a cross-cutting theme which offers a possible critical linchpin for moving forward policy or planning discussions within the domain of language education reform: the natural tension between importing a model versus importing a "cycle of discovery."

\section{Importation of models versus importation of "cycles of discovery"}

At this stage, one is obviously tempted to call for the widespread implementation of new programs based on the results of documented experiences from settings such as Canada, the Philippines, or some of the other countries mentioned previously. However, it may be instructive to underscore the observations made by Swain (1996) at an international conference on bilingualism held in Brunei Darussalam. There, she described some of the critical attributes of Canadian immersion programs. Swain also shared with participants the ways in which she and colleagues have continued to reflect upon the products of their earlier research in order to better understand and clarify some of the basic processes underlying successful and nonsuccessful language education. She described the need to "transfer" the stages and processes of evaluation, theory building, generation of hypotheses, experimentation, and further evaluation in order to help 
ensure that the implementation of programs is appropriate for the unique sociocultural contexts in which they will operate. That is, Swain cautioned that it is not a particular model of innovative language education (and, in particular, a Western model) that should be transferred, for example, to Brunei Darussalam or Namibia or Peru; but rather a "cycle of discovery."

Swain reminded us that the so-called threshold levels of L2 skills required for successful participation in formal education may differ quite dramatically across content areas, and that a majority of children face a language "gap" which must be bridged when they move from learning the target language to using the target language as a medium of instruction. Many policy makers have characterized bilingual education as a "high risk" undertaking, by which they mean that it is necessary to attend to a complex set of interacting educational, sociolinguistic, economic, and political factors.

\section{Implications for New Jersey Educators}

On the basis of experience in diverse settings over the past several decades, it seems that several sources of information can and should usefully inform the development and implementation of innovative language education programs in New Jersey: (1) an examination and understanding of the structure and capacity of the present educational system; (2) an examination of the results from a representative sample survey to examine diverse facets of the language situation in the state; and (3) an examination of the results from a purposeful set of studies conducted to examine language proficiency development and educational attainment under differing conditions (for example, results on state-mandated high school leaving examinations, if any; results on various components of the SATs; etc.)

The purpose of the remainder of this brief paper is to outline plans for an examination of the structure and capacity of the New Jersey educational system (indeed, large parts of this examination may have already been completed, and data assembled; but if not they probably should be).

\section{Studies of the Educational System}

A clear understanding of the structure and capacity of the current educational system will be an important element in any proposed educational reform. One useful model may be that followed and described by Harrison, Prator and Tucker (1975) in their work with the Jordanian Ministry of Education. In this regard, I recommend that comparable information be collected and analyzed with respect to the 
explicit and implicit goals of the New Jersey State Department of Education. In particular, I propose that investigators collect and examine information relevant to the following topics.

\section{Curricula and textbooks}

- Collect and analyze the existing curricula that currently guide and inform primary and secondary instruction in New Jersey

Special attention should be paid to the curricula for Spanish as a second language, for Spanish language arts, for English as a second language and for English language arts at each grade level.

Special attention should also be paid to describing the "policy context" within which Spanish and/or English are used as media of instruction and/or taught as subjects for study in various school districts.

- Collect and analyze the currently prescribed textbooks for each of the grade levels and subject areas (as appropriate)

Again, special attention should be paid to the language arts texts as well as to any texts that are to be used for the teaching of content material to students through a second language.

\section{Teacher education}

- Collect available information about the current teaching force. who are the current teachers? How can one characterize their training and experience? How can (if at all) one describe their language and subject-matter proficiency? On what bases are teachers evaluated (and retained, promoted or terminated)?

- Collect information about current professional development (inservice) opportunities for teachers. Are these optional or obligatory? What is the degree of participation? What information, if any, is collected about the effectiveness of such development activities?

- Collect information about current teacher education (preservice) programs. In what types of supervised teaching activities do candidates participate? What types of examinations or credentialing activities must they complete in order to be certified? If they are preparing for employment as language teachers, must they demonstrate some (minimal) level of proficiency in the target language?

What type of candidate enters a teacher preparation program? (For example, where do such candidates rank in terms of their secondary 
school achievement with others who enter the university?)

Approximately how many teachers enter the work force each academic year? What is the anticipated attrition? Is there at present a surplus or shortage of qualified teachers?

\section{Student performance}

- Collect and analyze existing standardized tests that are administered to students with a view toward understanding and documenting students' current reported achievement in relationship to some known benchmark.

How do New Jersey students perform in comparison with students in other states with similar concentrations of language-minority students?

\section{Conclusions}

Information such as that identified above would be collected and analyzed with the purpose to understand some of the factors that inevitably affect the academic performance (achievement) of New Jersey pupils; and also to understand some of the factors that could be manipulated in some type of planned educational reform.

As Courtney Cazden (1990) noted in her report for UNICEF, "despite the centrality of language achievements in the developmental agenda of the [child], language issues are rarely in the forefront of thinking about how to plan environments for young children." Also, that "The prevalence of multilingualism in the world adds a particular urgency to the recommendation to attend [to the quality of language instruction available to the child]."

The cumulative evidence from research conducted over the last three decades at sites around the world demonstrates conclusively that cognitive, social, personal, and economic benefits accrue to the individual who has an opportunity to develop a high degree of bilingual proficiency when compared with a monolingual counterpart. The message for educators is clear (see also, Tucker 1990): draw upon community resources and involve diverse stakeholders in all phases of program planning and implementation, implement carefully planned and well articulated sequences of study, utilize trained and committed teachers, and begin innovative language education programs that will lead to bilingual or multilingual proficiency for participants as early as possible. The graduates of such programs should be culturally rich, linguistically competent, and socially sensitive individuals prepared to participate actively in our increasingly global economy. 


\section{References}

August, Diane and Kenji Hakuta (eds.) Improving Schooling for Language-Minority Children: A Research Agenda. Washington, DC: National Academy Press, 1997.

Baker, Colin and Sylvia Prys Jones. Encyclopedia of Bilingualism and Bilingual Education. Clevedon: Multilingual Matters, 1998.

Brisk, María Estela. Bilingual Education: From Compensatory to Quality Schooling. Mahwah, NJ: Lawrence Erlbaum, 1998.

Cazden, Courtney, Catherine E. Snow and C. Heise-Baigorria. "Language planning in preschool education with 'annotated bibliography."' Report prepared for the Consultative Group on Early Childhood Care and Development, UNICEF, 1990.

Christian, Donna. "Language development in two-way immersion: Trends and prospects." In James. E. Alatis (ed.) Georgetown University Roundtable on Languages and Linguistics 1996. Washington, DC: Georgetown University Press, 1996. 30-42.

Cenoz, Jasone and Fred Genesee (eds.) Beyond Bilingualism: Multilingualism and Multilingual Education. Clevedon: Multilingual Matters, 1998.

Cheshire, Jenny (ed.). English Around the World: Sociolinguistic Perspectives. Cambridge: Cambridge University Press, 1991.

Comrie, Bernard. (ed.). The World's Major Languages. New York: Oxford University Press, 1987.

Crystal, David. The Cambridge Encyclopedia of Language. Cambridge: Cambridge University Press, 1987.

Cummins, Jim and David Corson (eds.). Second Language Education. Encyclopedia of Language \& Education: Volume 5. Dordrecht, Netherlands: Kluwer Academic Publishers, 1997.

Dutcher, Nadine in collaboration with G. Richard Tucker. "The use of first and second languages in education: A review of educational experience." World Bank, East Asia and the Pacific Region, Country Department III. Washington, DC, 1994.

Edwards, John. Multilingualism. London: Routledge, 1994. 
Gonzalez, Andrew. "Teaching in two or more languages in the Philippine context." In Jasone Cenoz and Fred Genesee (eds.) Beyond Bilingualism: Multilingualism and Multilingual Education. Clevedon: Multilingual Matters, 1998. 192-205.

Gonzalez, Andrew and Bonifacio P. Sibayan. Evaluating Bilingual Education in the Philippines (1974--1985). Manila: Linguistic Society of the Philippines, 1988.

Grimes, Barbara. F. Ethnologue: Languages of the World. Dallas: Summer Institute of Linguistics, 1992.

Hakuta, Kenji. Mirror of Language: The Debate on Bilingualism. New York: Basic Books, 1986.

Harrison, W., Prator, C. \& Tucker, G. R. English-Language Policy Survey of Jordan: A Case Study in Language Planning. Arlington, VA: Center for Applied Linguistics, 1975.

Lambert, Wallace E. "The two faces of bilingual education." NCBE Forum. 3, 1980.

Summer Institute of Linguistics. A Survey of Vernacular Education Programming at the Provincial Level within Papua New Guinea. Ukarumpa, Papua New Guinea: Summer Institute of Linguistics, 1995.

Swain, Merrill. "Discovering successful second language teaching strategies and practices: From program evaluation to classroom experimentation." Journal of Multilingual and Multicultural Development, 17: 1\&2, 89-104, 1996.

Thomas, Wayne P. and Virginia Collier 1996. "Language-minority student achievement and program effectiveness." NABE News 19, 6, 1996. 33-35.

Tucker, G. Richard. "Cognitive and social correlates of additive bilinguality." In James E. Alatis (ed.) Georgetown University Round Table on Languages and Linguistics: 1990. Washington, DC: Georgetown University Press, 1990. 90-101.

---. "Developing a language-competent American society: The role of language planning." In Allan. G. Reynolds (ed.) Bilingualism, Multiculturalism, and Second Language Learning. Hillsdale, NJ: Lawrence Erlbaum, 1991. 65-79. 
---. "Some thoughts concerning innovative language education programs." Journal of Multilingual and Multicultural Development. 17: $1 \& 2 \mathrm{M}, 1996$.

---. "A global perspective on multilingualism and multilingual education." In Jasone Cenoz and Fred Genesee (eds.) Beyond Bilingualism: Multilingualism and Multilingual Education. Clevedon: Multilingual Matters, 1998. 3-15.

Tucker, G. Richard and Richard Donato. "Developing a second language research component within a teacher education program." In James E. Alatis (ed.) Georgetown University Round Table on Languages and Linguistics: 1995. Washington, DC: Georgetown University Press, 1995. 453-470.

Tucker, G. Richard and David Corson (eds.). Second Language Education. Encyclopedia of Language \& Education: Volume 4. Dordrecht, Netherlands: Kluwer Academic Publishers, 1997.

World Bank. "Priorities and Strategies for Education." Washington, DC: The International Bank for Reconstruction and Development, 1995. 